\title{
From the President
}

\author{
David Pankratz \\ Loyola University Chicago
}

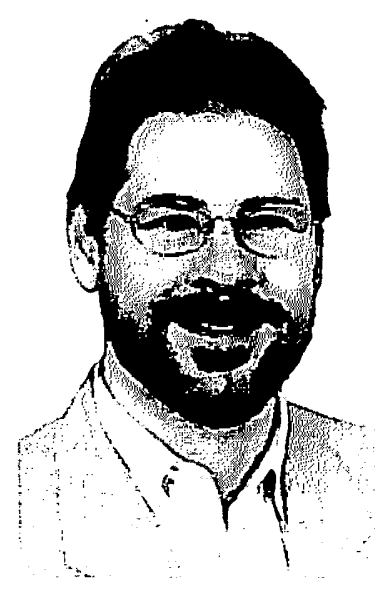

In these troubled times we are looking for answers to many questions. It ismysincere hope thatyou find answers to yours, and more specifically, that this organization helpyou find solutions to the many challenges facing all of us in our ongoing marriagecomplete with all the ups and downs-with technology. The members of this organization have a wealth of information to share, and in many ways the challenge is simply finding a way to share it effectively.

As I look back over my tenure as President, I see things that we accomplished and things that are still open-ended. Accomplishments made by your colleagues include:

- Completion of the "IALLT Statement of Professional Responsibilities." (www.iallt.org, About IALLT, Important Documents) This document packs a powerful punch, and I am confident it will serve us well for the future. A collaborative project among the membership, the Council and the Board, this powerful document defines in very thoughtful and comprehensive terms our professional duties and aspirations. I encourage you to take a close look and reflect how you can use it to explain, to advocate, to train, to advise. The document in its current form owes special thanks to Peter Liddell.

- Substantial development at the IALLT website. Thanksto Reid Paxton and Bruno Browning, our website looks and works as professionally as it ever has. Changes include member access to documents previously available only by separate purchase, information on consulting services, and more.

- Continued growth in our regular professional publication, the IALLT Journal. Current Editor Andrew Ross and his staff are challenging us to read and to contribute pieces of the highest qualityand interest. 
- Development of a new Council position for Digital Exchange Coordinator. As I write, this ambitious position is about to be filled. The Coordinator will lead a team of your colleagues to create a means to distribute digital materials integral to our work.

-Important discussions amongpublishing companies and members of the IALLT-Publishers TaskForce, led by Mike Ledgerwood. The fruit of thesediscussions have helped us better understand the issues that both bind us and distinguish usfrom commercial publishers. The results will be important in developing the Digital Exchange project mentionedabove.

- The Graduate Student Conference Grant, the first formalized financial support mechanism that IALLT has made available, by application, to needy graduate students. Everything we can do to promote the next generation of language technologists makes imminent sense to all of us.

- AnIALLTDonationsFund. Thisfund, enabledbyourstatus asanonprofitcharitableorganization, acceptstax-deductibledonationswhich feed into the Graduate Student Conference Grant or into the IALLT general fund, as designated by the donor. Who would like to contribute?!

-Along-awaited revision of the Management Manual, an extremely valuable reference book kept at arm's reach of many of our IALLT members. Ute Lahaie has taken on this project with vigor. Look for it at IALLT 2003.

- Another key revision of the Language Center Design Kit, edited by Jack Burston. This publication will also be on sale at IALLT 2003, hot off the presses!

- Continuedfunctioning of the LLTIlistserv, the conduitfor information so essential to our organization that we cannot imagine functioning without it. Take a bow, Otmar Foelsche.

- Ongoing collaboration with our affiliates, including CALCO, EUROCALL, LET and others. Thanks to all of you who serve to bridge the waters and share theinformation critical toall of us. Afine example of teamwork can be evidenced in the documententitled "Scholarly Activities in CALL." It was composed several years ago, butitis now posted at the websites of all organizations involved. How many 
language technologists doesit take to post a document? Onlya few, but they'reall volunteers...

I wantyou, as IALLT members, to be proud of the organization and the people who makeall of this collaboration possible. Itisimpossible for me to thank all of the gracious volunteers who give of their time and wit, butyou know whoyou are. In particular, I would like to thank the Executive Board with whom I have had the pleasure of working: Peter Liddell (President Elect), Lynne Crandall (Secretary), Lauren Rosen (Treasurer) and Harold Hendricks (Programs Director). They have served tirelessly, and it has been a genuine pleasure working with them. Read Gilgen, asPastPresident, hasalso been a tremendous resource to us, offering notonly the wisdom and perspective gained from his experience, butalso the hands-on assistance so essential to everysuccessful organization.

Thenew Board is beingelected as I write, and I welcome each of them heartily! They will perform fabulously under the capable hands of Peter Liddell, incoming President. Peter offers us the vantagepoint of one who knows "things international," an asset vital to our continued growth.

Mysincere thanks go to everyone who is busilyshaping the IALLT 2003 Conference taking place June 17-21 at the University of Michigan, from Monika Dressler (Conference Host) to Bruce Parkhurst (Program Committee Chair) to every single staff person and presenter who make this the premier learning experience for language technologists and lab administrators.

And mark your calendars for FLEATV, to take place August 5-10, 2005 hosted by Harold Hendricks at Brigham YoungUniversity. As those of you know who attended FLEAT III in Victoria, Canada or FLEATIV in Kobe, Japan, this is an event you won't want to miss.

You who know me also know that I am director of a modest-sized language lab at a modest-sized university. When Ineed astaff person to helpme, I checkmystudentemployee workschedule to see who's working the currentshift. Translation: Don'tever feel that your work oryour potential contribution to this organization is too small. IALLT depends on the energy and enthusiasm of each member to continue to thrive as an organization. Contact a Board member, any of the regional group leaders, or any of the other Council members to see howyou might become active. 
It has been a privilege serving the organization that made it possible for me to grow in my professional career, and I thank you for your support during my tenure as President. For a few answers to some of those unanswered questions... Ihope to see you in Ann Arbor! •

Sincerely,

David Pankratz 